\title{
A mélypontra sodródott kínai-magyar kapcsolatok (1960-1976)
}

\author{
Sino-Hungarian Relations at the Lowest Point (1960-1976)
}

\section{Wang Qiuping}

https://doi.org/10.47707/Kulugyi_Szemle.2020.4.05

Összefoglaló: Az 1960 és 1976 közötti időszak a kínai-magyar kétoldalú kapcsolatokban különleges időszak volt, amely a diplomáciai kapcsolatok felvételét követő tízéves politikai barátságot követte, illetve megelőzte a 1980-as évek főleg gazdasági célokat szolgáló barátságát. A kutatást megalapozó források hiánya miatt azonban ezzel a korszakkal kevesen foglalkoznak. A jelen tanulmányban a kínai-magyar elhidegülésre koncentrálva, a levéltári iratok és az érintettekkel készített mélyinterjúk alapján próbálom meg kínai oldalról feltárni, hogy miként alakultak az 1960-1976 közötti kínai-magyar kapcsolatok, milyen nemzetközi és belső tényezők voltak hatással azok fejlődésére, milyen szerepet játszott Kína a viszony romlásában, és milyen erőfeszítéseket tett a javításukra.

Kulcsszavak: kínai-magyar kapcsolatok, 1960-as évek, 1970-es évek, kínai-szovjet szakítás, Kína belpolitikája

\begin{abstract}
The period between 1960 and 1976 was a special period in Sino-Hungarian bilateral relations, which followed a 10-year-long political friendship after the establishment of diplomatic relations between the two countries and preceded the friendship of the 1980s, which was mainly for economic purposes. However, due to the lack of research materials, few scholars conducted special studies on the period from 1960 to 1976. This paper focuses on the cold period of SinoHungarian relations, through research on historical archives and in-depth interviews with historical witnesses, trying to explore from a Chinese perspective what Sino-Hungarian relations looked like between 1960 and 1976 and what international and internal factors influenced them, especially the roles of Chinese factors on bilateral relations.
\end{abstract}

Keywords: Sino-Hungarian relations, 1960s, 1970s, Sino-Soviet rift, China's domestic policy

\section{Bevezető}

1949. október 3-án Magyarország az elsôk között ismerte el az újonnan megalakult Kínai Népköztársaságot, és három nap múlva, október 6-án a két ország diplomáciai kapcsolatokat létesített egymással. Azóta a kínai-magyar kapcsolatok több történelmi időszakon mentek keresztül, amelyeket időrendben a barátság, az elhidegülés, az enyhülés és helyreállítás, a stabil fejlődés, valamint a korszakalkotó fejlődés jellemezte. A több mint 70 éves diplomáciai kapcsolatok közül általában az 1950-es, illetve a 2010 
utáni évek váltják ki a nagyobb érdeklődést a kutatókból, ugyanis az e két időszakra jellemző jó viszonyból eredően több feldolgozandó téma is kínálkozik számukra. Viszont a mélypontra süllyedt kínai-magyar kapcsolatokkal - kutatási anyagok híján - kevesen foglalkoznak.

A jelen tanulmányomban kínai oldalról vizsgálom az 1960-1976 közötti kínai-magyar kapcsolatokat. A levéltári iratok és az érintettekkel készített mélyinterjúk alapján próbálom feltárni, hogy milyen nemzetközi és belső tényezők akadályozták a bilaterális viszony fejlődését, Kína milyen szerepet játszott azok romlásában, és milyen erőfeszítéseket tett a kapcsolatok javulása érdekében.

\section{Az időszak háttere és jellegzetességei}

Az 1960 és 1976 közötti időszak a kínai-magyar kétoldalú kapcsolatok szempontjából különleges időszaknak számít, amely a diplomáciai kapcsolatok felvétele utáni tízéves politikai barátságot követte, és megelőzte az 1980-as évek - főleg gazdasági célokat szolgáló - együttmúködését. Ez az "összekötő kapocs" ugyanakkor nem tekinthető átmeneti időszaknak, ugyanis akkoriban számos belső és nemzetközi körülmény hatására a két fél közti viszonyra sok megpróbáltatás várt, s ennek messzemenő történelmi jelentősége van.

A vizsgálandó időszak a kínai-szovjet szakítással kezdődött, és a kínai kulturális forradalom befejezésével végződött. Akkoriban mind a nemzetközi, mind a kínai belföldi helyzet jelentősen megváltozott. Nemzetközi szinten Kína számára a kínai-szovjet viszony feszültsége, a szakítás és a későbbi széles körú szembenállás volt a legnagyobb kihívás, amely nagymértékben befolyásolta a kínai külpolitika fejlődési irányát és menetét, ennek következtében a pekingi vezetés átdolgozta az egész külpolitikáját és külügyi stratégiáját. Nemzeti szinten pedig a gazdasági és politikai területen felmerült belső gondok helytelen megoldása járt komoly diplomáciai következményekkel. Így a kül- és belpolitikai tényezők közös hatására a kínai-magyar kapcsolatok is mélypontra kerültek.

\section{Nemzetközi háttér: a kínai-szovjet szakítás}

A Szovjetunió Kommunista Pártjának (SZKP) 20. kongresszusa után Kína és a Szovjetunió között egyre hevesebb lett az ideológiai vita. Kezdetben azonban a nézeteltérések ellenére mindketten megpróbálták folytatni az együttmúködést és megőrizni a békét, mert a felek tudták, hogy együtt kell megvédeniük a szocialista tábor stabilitását és helyzetét, valamint a kínai-szovjet barátságos szövetségi kapcsolatot. Az összefogást célzó törekvések bukása után Peking és Moszkva között egyre több nyilvános vita és ideológiai összecsapás alakult ki. Mindkét fél "ellenintézkedéseket" tett a másikkal 
szemben. A Kínai Kommunista Párt (KKP) 1960 áprilisában három cikket jelentetett meg, amelyekben élesen bírálták a jugoszláv "modern revizionizmust”, és - a neve említése nélkül - elítélték Nyikita Hruscsov álláspontját. 1960 júniusában 51 ország kommunista és munkáspártja ülésezett Bukarestben, ahol Hruscsov és a kelet-európai kommunista pártok együttesen bírálták a KKP-t. Habár Peng Csen, a kínai delegáció vezetője az ülés után végül szintén aláirta a közös közleményt „az egység látszatának fenntartása és a kínai-szovjet kommunista pártok közötti nézeteltérések és kiélezett ellentétek csökkentése érdekében" (Liu, 1998, 101. o.), ezzel nem mérséklődött az ideológiai összecsapás.

A pártviszony megromlásával egyidejúleg a két ország közötti kapcsolat is mélyrepülésbe kezdett. 1960. július 28. és szeptember 1. között a Szovjetunió hazarendelte valamennyi tanácsadóját és szakértőjét Kínából (1390fő). Ezzel egy időben Moszkva megszegett tizenkét kínai-szovjet megállapodást, a tudományos intézeteiket érintő szerződés protokollját, továbbá 343 szakértői szerződést és szerződéskiegészítést, valamint leállított 257 tudományos és technológiai együttmúködési programot. Mindezek után nagymértékben csökkentette a Kína részére addig biztosított gyártó felszerelések és kulcsfontosságú technikai eszközök mennyiségét. E lépések sorozata az akkoriban egyébként is gazdasági problémákkal küzdő Kína számára csak tetőzte a bajt (Qi és Li, 2014, 46-47. o.). A szovjet szakértőknek Kínából történt 1960-as távozását követően a felek a vitát magasabb szintre emelték. ${ }^{2}$

A kínai-szovjet ideológiai vita és a két állam érdekeinek az összecsapása erősen befolyásolta a KKP-ben az akkori nemzetközi helyzet értékelését és a szocializmus értelmezését, továbbá a kínai belpolitikai helyzet megítélését, ami a későbbi „kulturális forradalom" kitörésének egyik fontos kiváltó oka lett (中共歷史研究局, 2011, 657. 0.).

1 A három cikk a következő: „Éljen a leninizmus!” (Peking: Népi Kiadó, 1960), „A nagy leninizmus útján haladunk!” (Zsenmin Zsipao, 1960. április 22.), „Összefogás Lenin zászlaja alatt!" (A KKP Propaganda Osztálya vezetője, Lu Ding-yi jelentése a Kínai Kommunista Párt Központi Bizottsága által szervezett rendezvényen, Lenin születésének 90. évfordulójára emlékezve).

2 1960. szeptember 17-22. között Teng Hsziao-ping, a KKP Központi Bizottsága főtitkára Moszkvába utazott, hogy ott a Szovjetunió Kommunista Pártjával tárgyaljon, de a megbeszélések nem jártak érdemi eredménnyel. November 10. és december 1. között 81 ország kommunista és munkáspártja találkozott Moszkvában, ahol a szovjetek és a többi ország kommunista pártjának képviselői folytatták a KKP-nek a "mozgalmon belüli széthúzás" vádjával történő kritizálását, mivel Kína újrafogalmazta a nemzetközi kommunista mozgalmak elvi alapját. A Varsói Szerződés 1961. márciusi és augusztusi csúcstalálkozóján, valamint októberben, az SZKP XXII. kongresszusán a Sztálin-kérdésről és Albánia helyzetéről folytatott vitát a két nagyhatalom. 1962 novembere és 1963 januárja között - a bulgáriai, a magyarországi, az olaszországi, a csehszlovákiai és a keletnémet pártkongresszuson - a Szovjetunió újra meg újra kritizálta Kínát, amire válaszul 1962. december 15. és 1963. március 8. között Peking hét elméleti cikket tett közzé a Szovjetunió és a mellette álló kommunista országok ellen. 1965 márciusában az SZKP és a kelet-európai országok intézkedéseket tettek a KKP ellen. 1966 januárjában Kína visszautasította az SZKP XXIII. Kongresszusára szóló meghívást, ezzel a kínai-szovjet pártviszony teljesen megszakadt. 


\section{Külügyi Szemle}

\section{Nemzeti háttér}

Kína belsó problémái

A belső tényezők közül elsősorban a kínai hazai helyzet befolyásolta a kínai-magyar kapcsolatokat. A két fél diplomáciai kapcsolatainak második évtizedében Peking két területen alakította át a belső struktúráját. Az egyik a "nagy ugrás" volt, amely a kínai gazdasági fejlődés felgyorsítását túzte ki célul, a másik pedig a "kulturális forradalom", amelytől azt remélték, hogy sikerül elkerülniük a kapitalizmus restaurációját és megvédeniük a KKP tisztaságát.

A "nagy ugrásra" utaló első jelzés Mao Ce-tungnak az 1957-es moszkvai konferencián, a szocialista pártok képviselői előtt mondott beszéde volt, amelyben bejelentette Pekingnek a kínai gazdasági fejlődés érdekében megvalósítandó egyik jelentôs célkitúzését, amely szerint Kína 15 éven belül le fogja hagyni Nagy-Britanniát az acéltermelésben. Nem sokkal később a kínaiak már a Moszkvában beharangozott időtávval sem elégedtek meg, és 3 évre csökkentették az acéltermelési célt, s ezzel párhuzamosan nagyszabású mezőgazdasági terveket is kidolgoztak. Az objektív gazdasági törvényeknek ellentmondó acéltermelési tervek kudarccal végződtek, így a kínai gazdaság kemény időszakot élt át.

Az ötvenes évek végén, a hatvanas évek elején Kínában egyre több belső probléma jelentkezett, viszont „az értelmiségiek egy jelentős része nem akarja látni, vagy nehezen érti meg a jelenlegi problémákat" (中共歷史研究局, 2011, 657. 0.). A kínai vezetés szerint ezért a rendszerrel elégedetlenkedő értelmiségieket át kellett nevelni. Csen Ji kínai külügyminiszter 1958. február 26-án a KKP által folytatott harccal és az értelmiséggel kapcsolatos problémával kapcsolatban arról tájékoztatta a Nyers Rezső által vezetett magyar szövetkezeti delegációt, hogy "a párt véleménye az, hogy minden értelmiséginek és nem fizikai munkát végző pártmunkásnak részt kell vennie a fizikai munka ilyen vagy olyan formájában. ... A vezetők, ha állandóan Pekingben ülnek, elszakadnak az élettől. Éppen ezért a KB minden egyes tagjának kötelező évenként négy hónapot vidéken, a dolgozók között élnie" (中共歷史研究局, 2011, 657. 0.). A hazai helyzet hibás értékelése következtében Peking újabb és újabb intézkedéseket hozott a jobboldaliság, a revizionizmus és a kapitalizmus restaurációja ellen. A szélsőséges baloldali eszmeáramlat hatására, illetve az éveken keresztül felhalmozott társadalmi ellentétek kitörése következtében 1966-ban elkezdődött a „kulturális forradalom", amely egy évtizedes ideológiai zúrzavarba és kegyetlen politikai megosztottságba taszította Kínát.

Bár a "kulturális forradalom" részben annak a következménye volt, ahogyan a KKP megítélte a nemzetközi helyzetet, de mivel az visszatükröződött a kínai külpolitikában is, ezért nem minősülhet egyszerúen Kína belpolitikai ügyének. A forradalom szellemében Kína akkoriban aktív vitába keveredett több tucat ország kormányával, mindössze 
egyetlen eggyel ápolt valóban pozitív viszonyt: az Albán Népköztársasággal (Kissinger, 2014,212 . o.). Peking az összes nagykövetét és a követségi személyzet közel kétharmadát hazarendelte vidéki átnevelésre vagy a forradalmi tevékenységben való részvételre, kivéve a Kairóba akkreditált, tehetséges és ideológiailag támadhatatlan Huang Huát (Macfarquhar és Schoenhals, 2008, 222-223. o.). A budapesti kínai nagykövetet is hazahívták, a kínai-magyar kapcsolat megbénult.

\section{A magyar bel- és külpolitika}

A kínai tényezők mellett a magyar bel- és külpolitika is hatással volt a kétoldalú viszonyra. Abban az időszakban Magyarország is nehéz helyzetben volt. Az ENSZ és Magyarország kapcsolatának az 1963-as normalizálása előtt a Kádár-rezsim nemzetközileg elszigetelődött. Ezen Kádár János két módon igyekezett enyhíteni: a szomszédos szocialista országok bizalmának elnyerésével, valamint a harmadik világ szovjetbarát, illetve el nem kötelezett államaival való kapcsolatok kiépítésével (Romsics, 2010, 922. o.). Ez utóbbi jegyében 1957 nyarán delegációk jártak Indiában, Burmában, Indonéziában, Nepálban, Ceylonban, Szíriában, Egyiptomban és Szudánban, illetve 1960ban Szukarno indonéz, 1961-ben Kwame Nkrumah ghánai elnök látogatott Budapestre (Romsics, 2010, 922. o.). A keleti tábor tagjaként a harmadik világ felé tett aktív diplomáciai lépésekkel nem sérthette meg a szovjet érdekeket.

Kádár számára a Szovjetunió bizalma és támogatása azért volt nélkülözhetetlen, mert Hruscsov volt a legfőbb patrónusa. Így a szovjet-kínai ideológiai vita alatt Kádárnak mindenképpen lojalitást kellett mutatnia az SZKP első titkára iránt.

Ezenkívül a magyarországi 1956-os eseménysorozat kétélű kard volt, amely egyszerre pozitív és negatív hatást gyakorolt a kínai-magyar kapcsolatokra. Egyrészt az 56-os forradalmat követő néhány évben a kínai kormány gyorssegélye és támogatása csúcspontra juttatta Peking és Budapest viszonyát, másrészt viszont a későbbiekben közvetett hatással is volt a kínai vezetésnek a hazai és a nemzetközi helyzetre vonatkozó megítélésére, és ez negatívan hatott vissza a kínai-magyar kapcsolatra. Például 1958 februárjában Csen Ji külügyminiszter az éppen Kínába látogató magyar szövetkezeti delegációval folytatott megbeszélésen felhozta, hogy "sokat tanultunk az eseményekből, főleg azt, hogy ha a volt burzsoá értelmiséget nem neveljük át, akkor nem lesz megbízható, és a kapitalizmus restaurációjára törekszik" (Magyar Nemzeti Levéltár Országos Levéltára, 1958). Ez az irányelv vezetett később a már említett kínai kulturális forradalomhoz, amelynek során hazarendelték a budapesti kínai nagykövetet is. 


\section{Külügyi Szemle}

\section{A kínai-magyar kapcsolatok az 1960-as évek elejétöl a kínai kulturális forradalom kitöréséig}

A kínai-szovjet kapcsolatban mutatkozó feszültségek fokozódása következtében Peking és Budapest viszonyában is némi válság tünetei jelentkeztek, amit például a Kínába látogató magyar politikusok beszédeiből érezhetünk. 1957-ben Kádár a KKP Központi Bizottságának - a Magyar Szocialista Munkáspárt (MSZMP) első titkárának látogatásával egyidejúleg rendezett - ülésén, a fentebb említett kínai-szovjet nézeteltéréseket félretéve, úgy mesélte el Mao Ce-tungnak az imperializmussal szembeni erőfölényt bizonygató felszólalását, mint "nagyon világos és érdekes" fejtegetést, s újra és újra a szovjet és a kínai nézetek egységét emlegette (Ormos és Vida, 2001, 19. o.). Továbbá azt hangsúlyozta, hogy a „politikailag, gazdaságilag és katonailag erős, legyőzhetetlen" szocialista tábort a Szovjetunió és Kína vezeti, s ezzel a Szovjetunióval azonos magasságba emelte az ázsiai országot (Vámos, 2008, 70. o.).

1959-ben azonban Kínáról már csak a szocialista tábor jelentős tagjaként esett szó. Dobi István 1959-ben, az Országos Népi Gyúlés Állandó Bizottságának és a Népi Politikai Tanácskozó Testület Állandó Bizottságának együttes, kibővített ülésén megköszönte az 1956-os eseményeket követó kínai segítséget, ám azt azért kihangsúlyozta, hogy akkor a szocialista tábor egésze támogatta a magyar kormányt (Vámos, 2008, 70. o.). 1960. szeptember 30-án Kádár utoljára vett részt a kínai nemzeti ünnep alkalmából rendezett nagykövetségi fogadáson, 1961-tól már távolmaradt a kínai hivatalos rendezvényekről. A magyarok Kína iránti hozzáállásában történt változásnak több oka is volt. Az egyik, hogy "a magyar pártvezetés számára Kína 1959-ben már közel sem játszott olyan jelentős szerepet, mint a korábbiakban, hiszen Magyarország túl volt az 1956-os megrázkódtatáson, és sikerült a kül- és belpolitikai helyzetet konszolidálni. A magyar-kínai kapcsolatok normálisan fejlődtek" (Ormos és Vida, 2001, 27. o.). A másik pedig a szovjet tényező figyelembevétele: bár még nem volt muszáj állást foglalni, már nem volt szabad tovább folytatni a kétirányú politikát.

A kínai-magyar viszony hajszálrepedései nemcsak a magyar fél részéről érződtek, hanem kínai oldalon is. A Kínai Népköztársaságban 1955-ig nem korlátozták a magyar diplomaták vidéki utazásait és látogatásait. Az utazási szándékot szóban kellett közölni a KNK Külügyminisztériumával, amely készségesen segített az utak megszervezésében. 1955 után írásban kellett benyújtani az igényt, ha valaki a Pekingtől 30 km-nél távolabb eső területekre kívánt eljutni. 1959 nyarán pedig a Kínai Államtanács határozatilag szigorította meg a baráti diplomaták utazását az ország területén. Attól kezdve általában csak Tiencsinbe, Nankingba, Sanghajba, Hangcsouba és Kantonba engedélyezték az utazást, más városokba csak igen ritkán. 1962-től aztán megnehezítették a baráti diplomatáknak a fővárosi üzem- és intézménylátogatásait is (Magyar Nemzeti Levéltár Országos Levéltára, 1965e). A kínai diplomaták számára Magyarországon a 
vidéki utazásokat, valamint az üzemek és intézmények látogatását 1961-ig a Külügyminisztérium (KÜM) Protokoll Osztályának megkerülésével, az illetékes szervekkel közvetlenül érintkezésbe lépve szervezték meg. Utána viszont - a kölcsönösség elvének fokozatos alkalmazásával - a KÜM igyekezett elérni, hogy a kínai nagykövetség diplomata munkatársai a látogatásaikat a Protokoll Osztály segítségével szervezzék meg (Magyar Nemzeti Levéltár Országos Levéltára, 1965e).

A kínai-szovjet vita elején Peking és Budapest viszonya még csupán kismértékben hidegült el, de 1963-tól már sokkal feltűnőbb lett a kapcsolat romlása, sőt az év fontos fordulópont lett. Márciustól a kínai-szovjet ideológiai összecsapás a nyilvánosság számára is egyértelmúvé lett, a vita sokkal szélesebb körű lett (az ideológia éles polémia mellett számos cikkben bírálták is a felek egymást). Miután 1963-ban az ENSZ visszaállította Magyarország tagságát, Hruscsov Budapestre utazott, majd Kádár elkísérte őt a Szovjetunióba, ahol több napos látogatást tett. A Kreml pedig éppen azalatt adta ki a „kínai elvtársakhoz intézett nyílt levelet", amely nemcsak nyilvánossá tette a Kína és a Szovjetunió közötti ideológiai vitát, de a két fél szakításához is vezetett. A szocialista országok vezetői közül így Kádár volt az első, aki szovjet újságban adott hangot a Kínával szembeni kritikának.

Ezt követően Kína és Magyarország kapcsolata rohamosan romlani kezdett, és sokkal hűvösebbé vált, mint amilyen az 1950-es években volt. Sok kérdésben folytak viták Peking és Budapest között, amelyek nem csupán a bilaterális ügyekre korlátozódtak, hanem sok egyéb területre is kiterjedtek, például a vietnami kérdésre, a pakisztáni-indiai konfliktusra, Csen Ji (kínai külügyminiszter) sajtónyilatkozatának a kérdésére stb. A felek nézeteltérése a kétoldalú államközi kapcsolatokra is negatív hatást gyakorolt: például a magyar fél az utolsó pillanatban lemondta egy magyar szakszervezeti küldöttség Kínába tervezett utazását, és nem fogadtak egyetlen egy kínai ösztöndíjast sem - ami miatt a budapesti kínai nagykövetség alacsony szinten ugyan, de több alkalommal is tiltakozott, s az eljárást „a magyar-kínai kapcsolatok tudatos megrontásának" minősítette (Magyar Nemzeti Levéltár Országos Levéltára, 1965b). A magyar kormánynak a KNK-val rossz viszonyban álló országokkal való kapcsolatai fejlesztésére irányuló törekvése - ahogy azt a magyarok is észrevették - „negatív hatást gyakorolt [a Kínához fúződő] politikai kapcsolatainkra" (Magyar Nemzeti Levéltár Országos Levéltára, 1965b).

Ugyanakkor annak köszönhetően, hogy néhány magyar politikus és diplomata jó kapcsolatot tartott fenn kínai politikusokkal, valamint a magyar vezetőknek a Kínával kapcsolatos 1960 előtti pozitív benyomásai hatására a kínai-magyar kapcsolatok romlása a pekingi-moszkvai kapcsolatoknál sokkal lassabb volt, és kevésbé észrevehetőnek tűnt (Vámos, 2012, 383. o.). Akkoriban Magyarország nyíltan kritizálta Kínát, a magyar sajtóban egyre több, a KKP-t közvetlenül támadó írás jelent meg, miközben a magánjellegú találkozókon a magyarok igyekeztek elkerülni a a kínai féllel való vitákat. Egy 1965ben fogalmazott iratban rögzítették is a kétoldalú kommunikációra vonatkozó alapelvet: 
„....továbbra is kell törekednünk minden területen az ideológiai vita káros hatásainak [a Kínával folytatandó] államközi kapcsolatainkból való kiküszöbölésére. A KNK hivatalos képviselőivel érintkező magyar személyek kerüljék a viták kezdeményezését; a vitákat kiváltható akciókat. Kínai részről történő kezdeményezés esetén nyugodt, higgadt hangnemben reagáljanak, lehetőleg ne a helytelen kínai nézetek közvetlen bírálásával, hanem a mi álláspontunk és gyakorlati tapasztalataink mellett való meggyőző érveléssel. Fokozottabban kell kezdeményezni együttműködést olyan területeken, mely területeken nézeteink egybeesnek, vagy közel állnak egymáshoz. Hangsúlyozottabban kell támogatnunk azokat a kínai külpolitikai akciókat és kezdeményezéseket, melyek összhangban vannak a szocialista tábor érdekeivel és az MNK alapvető külpolitikai irányvonalával." (Magyar Nemzeti Levéltár Országos Levéltára (1965d).

Az első tíz évben a szilárd alapokon épült barátság mellett talán az is számíthatott, hogy Magyarország nem mindig szívből jövően követte Moszkva utasításait, hiszen a levéltári iratokból jól látszik, hogy a magyarok „a kínai vezetés különálló nézeteit" említették, és "szembetúnő kínai külpolitikai tevékenységként" utaltak a kínai politikára (Magyar Nemzeti Levéltár Országos Levéltára, 1965b).

Kína sem akarta kiélezni az ellentétet, hiszen szüksége lett volna külső támogatásra. Az érzelmi közelségre tekintettel Peking szerette volna megnyerni Magyarországot a saját ideológiája támogatására: 1965. március 22-én Vince József, az új bukaresti magyar nagykövet bemutatkozó látogatása alkalmával Liu Fang, az ottani kínai nagykövet szóba hozta Csou En-laj 1957. évi magyarországi látogatását, és hasznosnak nevezte azt. Vince jelentése szerint „a kínai nagykövet sietett kijelenteni, hogy a segítségadásnak kölcsönösnek kell lennie, mintegy éreztetve azt, hogy akkor ők siettek segítségünkre, most pedig rajtunk lenne a sor a viszonzást illetően" (Magyar Nemzeti Levéltár Országos Levéltára, 1965f). A jelentés nem rögzítette, Vince hogyan reagált az utalásra, de nyilvánvaló volt, hogy a kínai-szovjet összecsapás közepette Magyarországnak mint kis országnak nem állt módjában a kínai kormány (nyílt) támogatása.

Budapest a Moszkva iránti lojalitása kimutatása érdekében továbbra is élésen kritizálta a kínai politikát, s emiatt a kínai vezetés elégedetlen volt. A bírálattal kapcsolatban többször is kijelentették, hogy „Kína sohasem támadja Magyarországot, illetve a KKP az MSZMP-t, magyar részról azonban sok támadás éri a KKP-t." ${ }^{\prime 3} \mathrm{~A}$ magyar diplomaták kötetlen, protokollmentes összejövetelek alkalmával azt javasolták a kínaiaknak, hogy tegyék félre, tompítsák és korlátozzák a vitát, hogy „az imperializmusnak ne legyen

3 Például Vu Hsziu-csuan (a KKP Központi Bizottsága Külügyi Osztályának helyettes vezetője) egyszer a Fock Jenő által vezetett magyar pártküldöttség pekingi átutazása alkalmából rendezett protokollmentes vacsorán azt mondta a magyar delegációnak: „Az utóbbi időben egyre több, a KKP-t közvetlenül támadó írás jelenik meg a Népszabadságban, bár mi egyetlen szóval sem támadtuk az MSZMP-t" (Magyar Nemzeti Levéltár Országos Levéltára, 1965c). 
alkalma kihasználni a köztünk lévő különbségeket" (Magyar Nemzeti Levéltár Országos Levéltára, 1965c). Erre a kínai fél nyíltan kimondta, hogy „ellentét van aközött, amit a magyar elvtárs mond, és amit a magyar sajtó tesz" (Magyar Nemzeti Levéltár Országos Levéltára, 1965c), és nem válaszoltak viszontüdvözléssel az MSZMP KB-nak és Kádár elvtársnak a pártküldöttség vezetője által átadott üdvözletére (Magyar Nemzeti Levéltár Országos Levéltára, 1965c).

A rengeteg nyílt vita ellenére a kínai-magyar barátság bizonyos szinten fennmaradt: a magyar politikusok és diplomaták közül sokan fenntartották a korábbi szoros együttmúködések által kialakított személyes jó kapcsolatokat és barátságot a kínaiakkal, s ez még a kínai-szovjet vita hevében is érzékelhető volt. Például az említett magyar pártküldöttséget 1965 októberében a pekingi Tiaojütaj kormányzati vendégházban fogadták, és a protokolltól mentes összejövetelen a felek között „érdekes beszélgetés alakult ki a kínai-szovjet vitáról" (Magyar Nemzeti Levéltár Országos Levéltára, 1965c). Az összejövetel után a magyar küldöttség kérésére a kínai fél látogatásokat szervezett számukra a pekingi elektroncsőgyárba, az I. számú Szerszámgépgyárba, az Országos Népi Gyúlés székházába, a nem sokkal korábban megnyílt japán gazdasági kiálításra, valamint a Nyári Palotába (Magyar Nemzeti Levéltár Országos Levéltára, 1965c). Ebből is láthatjuk, hogy a közepes rangú politikusok és diplomaták esetében megmaradtak a párbeszéd lehetőségei, sőt fenntartották az egymás iránti barátságot és bizalmat. Egy volt kínai kulturális tanácsos több alkalommal is úgy emlékezett minderre, hogy a magyar diplomaták a „termosz” és a „kacsaúszás” szóképekkel fejezték ki a Kína iránti érzelmüket. ${ }^{4}$

A hivatalnokok közötti barátság mellett a közemberek közti jó kapcsolat is nagyjából megmaradt. Az 1960-as években ösztöndíjjal az ELTE-n tanult kínaiakkal készített interjúim során többen kifejezetten hangsúlyozták, hogy „a politikai kapcsolatok romlása ellenére a népek közötti barátság fenntartottuk, a magyar nép még mindig kedves volt a kínaiakhoz". Úgy emlékeztek, hogy „a hatvanas évek elején pezsgő eszmecseréket folytattunk a magyar egyetemistákkal: sokat beszéltünk az ideológiáról és az aktuális politikáról, hiszen mindenki fiatal volt, nem akartunk bedőlni az újságoknak. A magyar diákok az igazi Kínáról szerettek volna tudni. Voltak viták is közöttünk, néha hevesek, de a vitatkozás után nem maradt ellenérzés. Továbbra is meghívtak minket vendégségbe, továbbra is együtt kirándultunk, ünnepek alkalmával továbbra is ajándékokat cseréltünk. Szerettük egymást mindvégig." ${ }^{5}$ Ezek a személyes jó kapcsolatok aktív szerepet játszottak a politikailag nehéz években, és a zűrzavaros időszak elmúltával a hivatalos reláció helyreállításához is hozzájárultak.

\footnotetext{
4 Termosz: kívül hideg, belül meleg; kacsaúszás: a vízen úszó kacsa látszólag mozdulatlanul úszik, de a víz alatt sok mozdulatot tesz.

5 A szerző által készített interjú.
} 


\section{Külügyi Szemle}

A kínai-szovjet ideológiai vita kialakulásától a kínai kulturális forradalom kitöréséig terjedő időszakban a kínai-magyar gazdasági-kereskedelmi forgalom nagymértékben visszaesett. Ez „a politikai kérdésekben fennálló nézeteltéréseket mutatja a legvilágosabban" (Magyar Nemzeti Levéltár Országos Levéltára, 1965a). Az 1960-as évek elején a felek közötti kereskedelmi forgalom már meg sem közelítette a kommunista mozgalomban kialakult vita elótti szintet, és utána évről évre csökkent (1. táblázat):

1. táblázat ${ }^{6}$

A magyar külkereskedelmi forgalom Kínával 1957-1964 között (millió új rubel)

\begin{tabular}{|c|c|}
\hline 1957 & 87,0 \\
\hline 1958 & 111,3 \\
\hline 1959 & 67,4 \\
\hline 1960 & 74,7 \\
\hline 1961 & 29,5 \\
\hline 1962 & 23,8 \\
\hline 1963 & 18,2 \\
\hline 1964 & $18-19$ \\
\hline
\end{tabular}

Az 1964. évi magyar követi jelentés szerint „ez a kínai vezetés szándékát tükrözi, mivel ugyanezt tapasztaljuk a cseh-kínai, a bolgár-kínai és a mongol-kínai viszonylatban is" (Magyar Nemzeti Levéltár Országos Levéltára, 1965a). A vonatkozó kínai levéltári anyag ismeretének hiányában nem tudni, hogy ők minek tudták be a visszaesést. Az egyik lehetséges okként érdemes megemlíteni, hogy a kínai fél több éven keresztül folyamatosan reklamált a magyar árucikkek minősége miatt, például „többször kellett Kínába brigádokat küldeni, hogy utólag javítsák ki a gépeken azokat a hibákat, amiket Magyarországon nem vettek észre" (Vámos, 2008, 26. o.). Kína számára a magyar teljesítőképesség korlátai és a gyakori minőségi hibák miatt a kevésbé fejlett nehéziparral rendelkező Magyarország nem volt igazán jó kereskedelmi partner.

Az 1964-es év passzívummal zárult a magyar fél számára, aminek több oka lehet. Egyrészt a kínai gazdasági helyzet némi javulást mutatott,? amire a magyar levéltári iratokban is lehet találni bizonyítékot: „a kínai vezetés értékelése szerint 1964-ben alapjában véve sikerült megoldani azokat a gazdasági nehézségeket, amelyeket az

6 Forrás: Magyar Nemzeti Levéltár Országos Levéltára, 1965a.

7 Csou En-laj kínai miniszterelnök az Országos Népi Gyülés 1964. decemberi III. ülésszakán tartott beszámolójában a gazdasági helyzetről szólva bejelentette: „1964-ben alapjában véve befejeződött a népgazdaság rendezése, és az egész népgazdaság... új fejlődési szakaszba lépett." 
1958-60-ig tartó nagy ugrás hibái és kisebb mértékben az 1959-61-es évek természeti csapásai okoztak... 1964-ben ezen intézkedések hatására további jelentős emelkedést értek el mind az ipar, mind a mezőgazdaság fóbb ágazataiban" (Magyar Nemzeti Levéltár Országos Levéltára, 1965b). Másrészt mind a kínai, mind a magyar fél szerette volna kiküszöbölni az ideológiai vitának az államközi kapcsolatokra is kiterjedt káros hatásait, amely lehetővé tette, hogy Kína több terméket exportálhasson Magyarországra.

Ugyanabban az évben a kínai-magyar kapcsolatok alakulásában bizonyos - ha nem is alapvető - javulás volt tapasztalható. Ez megmutatkozott mind a kulturális és múszaki együttműködés, mind a vitás gazdasági kérdések megoldása terén.

"A kulturális munkaterv fő pontjait 1964-ben lényegében teljesítettük. Tapasztalataink általában jók. Kiutazóinkkal csak elvétve fordult elő, hogy kínai részről politikai vitába keverték volna őket. Ilyen csak Hruscsov elvtárs felmentésével kapcsolatban történt. Múvészeti csoportunk tevékenységét igen hasznosnak értékeljük. Ugyanezt már nem mondhatjuk el fényképkiállításunkról, amelynek anyaga nem tükrözte megfelelően a magyar fényképészet eredményeit és hazánk szocialista fejlődését. 1964-ben sikerült néhány olyan problémát megoldanunk, amelyek mindkét ország számára kellemetlenséget okoztak. Megoldottuk többek között a Ganz-ügyet, a magasnyomású tekercselt testek ügyében benyújtott reklamációt, valamint a filmreklamációt." Magyar Nemzeti Levéltár Országos Levéltára (1965a).

Több bizalmas dokumentumból is érződik a magyaroknak a Kínával való kapcsolatok javítására való hajlandósága. Egy 1965-ös irat úgy fogalmaz, hogy „Kínában 1966-ban elkezdik a harmadik ötéves tervet, arra kell törekedni, hogy az ötéves terv keretén belül a lehetőségeink figyelembevételével hosszú lejáratú műszaki és kereskedelmi megállapodásokat kössünk" Magyar Nemzeti Levéltár Országos Levéltára (1965a). Sajnos, az 1966-ban kitört kulturális forradalom miatt ez az elképzelés nem valósult meg, utána pedig egyre rosszabb lett a helyzet.

\section{A kínai-magyar kapcsolatok 1966-1976 között}

1966-tól a kínai-magyar kapcsolatok háttere megváltozott. A közel tíz évig tartó „kulturális forradalom" alatt megszakadt szinte minden hivatalos viszony Peking és Budapest között. A kínai nagykövet, Han Kehua 1967 augusztusában visszatért hazájába, ezután három évig Kínának nem volt kirendelt nagykövete Magyarországon. az őt váltó Lü Zhixian csak 1970 augusztusában foglalta el pozícióját.

Egy magyar dokumentum szerint „a [Kínával való] kapcsolataink 1967 nyarára a mélypontra zuhantak. A pártjaink közötti kapcsolatok 1965 óta szünetelnek. A normális államközi kapcsolatok lényegében szünetelnek" Magyar Nemzeti Levéltár Országos Levéltára (1968). A magyarok szerint a két ország viszonyára az alapvető negatív 


\section{Külügyi Szemle}

hatással a kínai vezetők szakadár, nagyhatalmi-soviniszta politikája volt, amely az ún. „nagy proletár kulturális forradalomban" tetőzött Magyar Nemzeti Levéltár Országos Levéltára (1968). Budapesten úgy értékelték, hogy "a pártunk és kormányunk, mint a "Szovjet revizionista klikk első számú követője«, többször is céltáblája volt még 1967ben [a kínai támadásoknak]. Ez fő oka annak, hogy nem sikerült realizálni az MSZMP KB 1965. szeptemberi határozatát, mely célul tǔzte ki a magyar-kínai kapcsolatok meglévő szintjének fenntartását, ill. a lehetőségek szerinti emelését" Magyar Nemzeti Levéltár Országos Levéltára (1968).

Ezzel kapcsolatban azok a kínai interjúalanyaim, akik személyesen megtapasztalták ezt az időszakot, úgy vélték, hogy nem annyira a kínai-magyar vita, sokkal inkább a kínai belpolitika miatt tért haza a kínai nagykövet. Han Kehuával a nagykövetségen dolgozó számos diplomata is hazatért 1967-ben, csupán néhányan maradtak, hogy felügyeljék az épületet. A diplomaták hazatérésének a közvetlen oka a kulturális forradalom során meghirdetett, a „külpolitikai privilégiumok elleni” kampány volt. Az egyik - a neve elhallgatását kérő - interjúalany visszaemlékezése szerint a kínai bécsi kereskedelmi kirendeltségen volt valaki, aki jelentette Pekingnek, hogy a Bécsben állomásozó kínai diplomaták számára bizonyos privilégiumok élvezetét, például felsőkategóriás autók használatát biztosítják. Miután erről tudomást szereztek Kínában, nagyon komolyan vették ennek a jelentőségét, és megkövetelték, hogy a nagyköveti, konzuli pozíciót betöltő személyek utazzanak haza a világ minden tájáról, és vegyenek részt a kulturális forradalomban. A diplomaták a hazautazásuk után azonnal belevetették magukat a "forradalomba": az Idézetek Mao Ce-tung elnöktôl címú kiadványt (vagyis „a kis vörös könyvet") tanulmányozták, "demokráciafalat" emeltek, később pedig falvakba rendelték őket átnevelésre. Vidéken a parasztok között rizst vagy búzát termeltek, házat építettek, téglát égettek, hivatali ügyekkel azonban nem foglalkozhattak. Egy-kétéves fizikai munka után a magyarul beszélő kádereket tolmácshiány miatt visszahívták Pekingbe, s onnan sokan visszamentek az eredeti állásukba.

Az új budapesti kínai nagykövet 1970 nyarán érkezett Magyarországra, és a normális nagykövetségi munka hamarosan helyreállt. A kulturális forradalom legkeményebb éveit átvészelve, a hetvenes évek elején kicsit javult a kínai-magyar viszony, kevesebb vita vetődött fel a kulturális forradalom igazságával kapcsolatban. A nézeteltérések központi témája Tajvan és Tibet szuverenitásának kérdése lett, amely ismét erősítette az ellentétet Kína és Magyarország között. A rossz viszony így csak a hetvenes évek végén, a nyolcvanas évek elején kezdett javulni.

Annak ellenére, hogy Kína főleg belpolitikai okokból hívta haza a diplomatákat Magyarországról, nem lehet tagadni, hogy a két párt nézeteltérése súlyosbította a feszült helyzetet. Az egyik, akkoriban az ELTE-n tanuló riportalanyom így mesélt a kínai-magyar politikai feszültségről: 
„1966-ban, mielőtt hazamentem, a Magyar Postán feladtam a Magyarországon vásárolt összes könyvem, aztán a pekingi átvételükkor a helyi vámhivatal vezetője személyesen ellenőrizte azokat. Mivel nem tudott magyarul, tőlem kérdezte, hogy a könyvekben megtalálhatók-e a marxizmus vagy Mao eszméi. Azt feleltem, hogy nem. Erre kijelentette, hogy az 1956 után kiadott könyvek mind revizionistának minősülnek, tilos bevinni őket az országba, hacsak nincsenek bennük a marxizmus vagy Mao eszméi. Könyörögtem neki, hogy legalább a két legvastagabb tankönyvem megmaradhasson. Erre megint kérdezte, hogy megtalálhatók-e bennük a marxista vagy a maoista eszmék, de mivel ismét azt mondtam, hogy nem, végül az összes könyvem elvették, hiszem mindegyik 1956 után jelent meg."

Ebből az esetből is láthatjuk, hogy abban az időben a politikai értékek mindenek fölött álltak. 1966-tól hazaküldték a kínai ösztöndíjasokat Magyarországról, és a kínai-magyar kulturális kapcsolatok is nagymértékben visszaestek. „Vita alakult ki az ösztöndíjas cserével kapcsolatban, amelyet kínai részről az utóbbi időben pártunk és kormányunk politikájának támadására használnak fel" Magyar Nemzeti Levéltár Országos Levéltára (1966).

1968-ban - a kínai-magyar kapcsolatok történetében először - nem írtak alá a felek kulturális munkatervet. „Még az 1967-ben aláírt - és a felek szóbeli megállapodása alapján 1968-ra átvitt - munkatervet sem sikerült teljesíteni, pedig maga a munkaterv mindössze egy érdemi pontot tartalmazott, és megkötésének célja az volt - 1967. december 8-án került sor az aláirásra -, hogy elkerüljék a kapcsolatok teljes megszakadását" Magyar Nemzeti Levéltár Országos Levéltára (1969).

„A kínai fél 1968-ban semmi kezdeményezést nem tett a kapcsolatok fenntartása érdekében. Sőt, 1968. november 19-én a Külügyminisztérium Szovjet [és] Kelet-európai Főosztályán Liu Tie-seng és Csen Csi-liu közölték: Kínában a kultúrforradalom teljes győzelméért harcolnak, s mindenki nagyon el van foglalva. Ezért javasolják: idén ne tárgyaljunk kulturális munkatervről, s a tavalyi terv értelmében küldendő személyeket a kínai fél nem szándékozik elküldeni" Magyar Nemzeti Levéltár Országos Levéltára (1969).

Kína és Magyarország 1966-tól egészen 1982-ig nem cserélt ösztöndíjasokat egymással, aminek hosszú távú hatása is lett. Mire eltelt ez a nehéz másfél évtized, a kapcsolat helyreállításához már nem volt elég fiatal tolmács és Magyarország-barát ember tartalékban. Így az egyetlen kínai nagykövetségi tolmács - aki 1959-től 1963-ig az ELTE-n tanult ösztöndíjasként, 1970-től 1992-ig pedig öt kínai nagykövet mellett dolgozott tolmácsként a budapesti kínai nagykövetségen - csak az ötvenes éveiben tudta 


\section{Külügyi Szemle}

áthárítani a tolmácsolás terhét az új generációnak. A kínai-magyar diplomáciatörténetben a politikai értékek összecsapásának a kulturális és oktatási területre gyakorolt negatív hatása egy-két generációra szólt.

A szovjet tényezó és a kínai kulturális forradalom következtében majdnem minden hivatalos kínai-magyar kapcsolat megszakadt, és a két ország sokszor ellenségnek tekintette egymást. ${ }^{8}$ A nem hivatalos kapcsolatok megőrzése érdekében kínai részről meghirdették a „Menj ki, és invitáld be őket!" politikát.

E szlogen első fele a kifelé terjesztett propagandára utal: Kínának kezdeményező szerepet kell vállalnia a magyar néppel való barátság kialakításában. Ennek megfelelően Magyarország különböző pontjain a kínai népviseletet, különböző kínai festészeti stílusokat és kínai porcelánokat bemutató kiállításokat rendeztek. Néhány éven belül e tárlatok bejárták az ország mind a 19 megyéjét, és a gyakorlat azt mutatta, hogy a magyarok nagy érdeklődéssel fogadták a kiállított tárgyakat. A budapesti Kínai Nagykövetség kulturális osztályának egyik munkatársa a Budapesti Közlekedési Múzeumhoz fúződő személyes kapcsolatán keresztül elérte, hogy ott több alkalommal is tarthattak rendezvényeket, például kínai filmvetítést, sőt kínai ételkóstolót is, amelyen a magyaroknak lehetőségük nyílt ingyenesen megízlelni többek között a nagykövetség séfje által készített kínai gőzölt batyukat és csípős-savanyú levest.

A jelmondat második fele, a "beinvitálás" olyan eseményeknél valósult meg, mint például a nagykövetség által rendezett, filmvetítéssel egybekötött fogadások. Olyankor meghívták a Kínával jó barátságot ápoló magyarokat a nagykövetségre közös filmnézésre és az azt követő állófogadásra. A két ország viharos kapcsolatának időszakában kevés Kínát bemutató könyv, újság jelent meg Magyarországon. Pedig a magyar diákság, fiatalság és általában a teljes lakosság érdeklődéssel fordult Kína felé, és szerették volna jobban megismerni az országot, ezért gyakran megtörtént, hogy a nagykövetségtől kértek prospektusokat, bemutató anyagokat. A nagykövetség közelében lévő általános és középiskolák diákjai gyakran látogattak el oda, hogy kínai tájakat ábrázoló képeslapokat kérjenek - e kéréseket a nagykövetség mindig maradéktalanul teljesítette. Így azokban az években, amikor a két ország közötti hivatalos kapcsolattartás szünetelt, Kínának a meghirdetett stratégiája segítségével mégis sikerült fenntartania a kapcsolatot a magyar néppel. A hivatalos kulturális és oktatási kapcsolatok viszont csak a nyolcvanas években álltak helyre.

8 Például „a kínai nép ellenségének" minősítették Piszker Tibor ezredest, Magyarország pekingi katonai attaséját. A magyar dokumentum szerint „erre egy 1967-es dél-kínai utazása során adott okot", és „a kínaiak ez esetben nyilván retorziót alkalmaztak" (Magyar Nemzeti Levéltár Országos Levéltára, 1968). 


\section{Összefoglalás}

A szovjet-kínai szakítástól a kulturális forradalom végéig terjedő időszakban a kínaimagyar politikai viszony mélypontra zuhant, s ennek következtében a hivatalos kapcsolat minden egyéb területen is csaknem megszakadt. Akkoriban a politikai értékek különbözősége (a kínai-szovjet ideológiai vita és a kínai kulturális forradalom okozta kínai-magyar politikai nézeteltérés) erősen befolyásolta a kétoldalú politikai, gazdasági-kereskedelmi, illetve kulturális-oktatási kapcsolatok fejlődését. Az 1960-as évek elejétől Kína és Magyarország között hivatalos szinten már egyre kevesebb lett a magas rangú cserelátogatás, a kulturális csere is jelentősen ritkult.

Noha a kínai-szovjet szakítás elején a magyar külpolitika rugalmasságának köszönhetően a kínai-magyar kapcsolatok a hivatalos látszatnál kevésbé sérültek, a regreszszív tendencia mégis erőteljesen érzékelhető volt, a kínai kulturális forradalom negatív hatására pedig a diplomáciai kapcsolat csaknem megszúnt. Ezzel egyidejúleg a hivatalos kulturális-oktatási kapcsolatokból is alig maradt valami, ami a puha hatalom szempontjából károsan befolyásolta a két nép közötti barátságot is. Szerencsére a kínai-magyar reláció első tízéves barátságának köszönhetően a két ország politikai viszonyának megromlása nem tette tönkre a népeik közötti informális kapcsolattartást. Ez utóbbi pedig nagymértékben hozzájárult ahhoz, hogy a két fél között a kapcsolatok minden területen helyreállhattak.

\section{Irodalomjegyzék}

Kissinger, Henry (2014). Kínáról. Budapest: Antall József Tudásközpont.

Liu， Xiao (1998). 出使苏联八 (1955-1962) [Diplomataként voltam nyolc évig Szovjetunióban]. Peking: KKP Központi Párttörténeti Kiadó.

Macfarquhar, Roderick és Schoenhals, Michael (2008). Mao's Last Revolution. Cambridge, MA: Harvard University Press.

Magyar Nemzeti Levéltár Országos Levéltára (1958). Száll József ideiglenes ügyvivő jelentése a Külügyminisztériumnak Csen Ji külügyminiszternek a Nyers Rezső vezette magyar szövetkezeti delegációval folytatott megbeszéléséról. Külügyminisztérium bizalmas iratai 1945-1964. MOL XIX-J-i-j, 9. doboz, 5/e. 003 133/1958.

Magyar Nemzeti Levéltár Országos Levéltára (1965a). 1964. évi követi jelentés. Előadó: Újlaki, Peking, 1965. február 5. MOL KüM Szt, XIX-J-1-j, 1965, 70. doboz, 001832.

Magyar Nemzeti Levéltár Országos Levéltára (1965b). A KNK helyzete és a magyar-kínai kapcsolatok alakulása 1964-ben. Előadó: Újlaki György, Szabados László, Budapest, 1965. január 16. MOL KüM Szt, XIX-J-1-j, 1965, 70. doboz, 16/1965.

Magyar Nemzeti Levéltár Országos Levéltára (1965c). A magyar pártküldöttség átutazása Pekingen. Előadó: Iván László. 1965. október 17. MOL KüM Szt, XIX-J-1-j, 1965, 70. doboz, 004887/1-206/1/1965. szig.t. 


\section{Külügyi Szemle}

Magyar Nemzeti Levéltár Országos Levéltára (1965d). Feljegyzés: Direktívák a magyarkínai államközi kapcsolatok fejlesztésére (javaslat). Előadó: dr. Újlaki György, 1965. MOL KüM Szt, XIX-J-1-j, 39/1965, 70. doboz.

Magyar Nemzeti Levéltár Országos Levéltára (1965e). Feljegyzés: „A kínai nagykövet látogatásai", előadó: Újlaki György, Budapest, 1965 április 14. MOL Küm Tük XIX-J-1j-Kína 172. doboz, Mozgáskorlátozás, IV-1541-71-1965.

Magyar Nemzeti Levéltár Országos Levéltára (1965f). Látogatás Liu Fang kínai nagykövetnél; előadó: dr. Gerlán László, Bukarest 1965. március 24. MOL KüM Szt, XIX-J-1-j, 1965, 70. doboz, 002478/1-85/2/1965.

Magyar Nemzeti Levéltár Országos Levéltára (1966). Rövid összefoglaló a Kínai Népköztársaság helyzetéről és a magyar-kínai kapcsolatok alakulásáról - a követi konferenciához. 1966. november 30. MOL KüM Szt, XIX-J-1-j, 21. doboz, 47/1969, 003650/12/1966.

Magyar Nemzeti Levéltár Országos Levéltára (1968). Negatívumok és pozitívumok a magyar-kínai kapcsolatokban. 1968. június 12. MOL KüM Szt, XIX-J-1-j, 1965, 70. doboz, 001500/1/1968.

Magyar Nemzeti Levéltár Országos Levéltára (1969). Huszár Flórián beszámolója. 1969. május 28. MOL KüM Szt, XIX-J-1-j, 21. doboz, 47/1969, 002227/1/1969.

Ormos Mária és Vida István (2001). Magyar-kínai kapcsolatok 1956-1959: dokumentumok. Budapest: MTA Jelenkorkutató Bizottság.

Qi, Pengfei és Li, Baozhen (2014). 新中国外交简史 [Az új Kína rövid diplomáciai története]. Peking: People's Publishing House.

Romsics Ignác (2010). Magyarország története. Budapest: Akadémiai Kiadó.

Vámos Péter (2008). Kína mellettünk? Kínai külügyi iratok Magyarországról, 1956. Budapest: MTA Történettudományi Intézete.

Vámos Péter (2012). 1956-1966年匈中关系的变化 [A kínai-magyar viszony megváltozása, 1956-1966]. Peking: China Academic Journal Electronic Publishing House.

中共歷史研究局 [A KKP történeti kutatási irodája] (2011). 中国共产党历史・第二卷 (1949-1978) [A KKP története. Második kötet (1949-1978)]. Peking: KKP Központi Párttörténeti Kiadó. 